Artykuł Wiesława Jamrożka przedstawia wszechstronny obraz dokonań w dziedzinie historii wychowania Heleny Radlińskiej. Autor ukazał w nim wkład H. Radlińskiej w kształtowanie się podstaw metodologicznych historii wychowania, a także podkreślił znaczenie jej dorobku piśmienniczego, w którym sporo miejsca zajmowała biografistyka edukacyjna. Autor podkreśla, iż „Helena Radlińska interesując się szczególnie dziejami oświaty pozaszkolnej i pracy społecznej znacznie poszerzala dotychczasowy przedmiot badań historii wychowania (sytuujący się tradycyjnie wokół zagadnień szkolnych i tzw. pedagogiki szkolnej)". W jej stanowisku dostrzec można zalażki społecznej orientacji w badaniach historyczno-edukacyjnych. Akcentuje również jej wkład w rozwój badań regionalnych, gdyż „,bez ich wyników trudno kreślić większe obrazy przeszłości, ujmować szersze i bardziej całościowe problemy historii wychowania".

Kolejną część II działu stanowią rozważania Danuty Koźmian dotyczące Jana Hulewicza i jego miejsca w historii wychowania XX wieku. Autorka ukazała różnorodne formy i problematykę podejmowana przez Jana Hulewicza w jego pracy naukowo-badawczej. Przedmiotem zainteresowań Jana Hulewicza były zagadnienia oświaty i nauki w okresie zaborów oraz $w$ dwudziestoleciu międzywojennym: walka o szkolę polską w Galicji, walka kobiet polskich o dostęp do nauki i uniwersytetów, powstanie i rozwój Akademii Umiejętności, rola Szkoły Głównej w życiu narodu polskiego, dzieje Uniwersytetu Jagiellońskiego, znaczenie serii wydawniczej Biblioteka Narodowa dla rozwoju nauki i kultury, dzieje ruchu nauczycielskiego w Polsce, życie i działalność Stanisława tempickiego.
Kolejny artykuł autorstwa Eleonory Sapii-Drewniak poświęcony jest Józefowi Madei, który zajmował się problemami oświaty i wychowania dotyczącymi Śląska. Koncentrował się on glównie wokół następujących problemów: walka o polskość i szkolę polska na Ślasku, działacze ruchu narodowego, dzieje elementarzy na Śląsku.

Autorka szkicu podkreśla, iż „chociaż zainteresowania naukowe J. Madei w zakresie historii oświaty ograniczone zostały do regionu Śląska, to zawsze starał się on ukazywać problemy występujące $w$ tym regionie jako integralną część historii Polski".

W kolejnym szkicu Katarzyna Kalinowska przyblizyła działalność naukową Stanisława Tynca, który rozwijał głównie zagadnienia związane z dziejami szkolnictwa na Pomorzu. Jego publikacje wniosły poważny wklad w historiografię Pomorza, a w szczególności Torunia. Zarówno jego praca naukowa, jak $\mathrm{i}$ dydaktyczna miały na uwadze krzewienie polskości. Publikując szereg artykułów w ogólnodostępnej prasie popularyzował naukę akcentując wartości moralne $\mathrm{i}$ narodowe.

Rozdział II kończy komunikat Tadeusza Jałmużny dotyczący Michała Janika, autora popularnego opracowania Dzieje szkolnictwa polskiego z rzutem oka na jego przysztość. Autor podkreśla, iż Michał Janik interesował się historią oświaty, szkolnictwa i kultury polskiej, ponieważ świadczy o tym pozostawiony przez niego dorobek naukowy.

Trzecia część niniejszej pracy zatytułowana In Memoriam jest wyrazem szacunku dla niedawno zmarlych historyków wychowania: Profesor Mirosławy Chamcówny i Profesora Wacława Marmona.

Danuta Apanel

\title{
Inspiracje dla współczesnej edukacji w dydaktyce Drugiej Rze- czypospolitej, pod red. Danuty Dryndy, Katowice 2000, ss. 130
}

Publikacja Wydawnictwa Uniwersytetu Śląskiego poświęcona koncepcjom teoretyczno-metodologicznym w dydaktyce Drugiej Rzeczypospolitej, dostarczająca inspiracji dla współczesnej edukacji, stanowić będzie zapewne cenną pomoc dla osób zajmujących się organizacją i rozwojem dzisiejszej dydaktyki.

Omawiana pozycja stanowi zbiór siedmiu artykułów, z których trzy pierwsze - Sławomira Sztobryna, Władysławy Szulakiewicz oraz Danuty 
Dryndy - ukazują różne stanowiska prezentujące sposoby uprawiania dydaktyki jako dyscypliny naukowej. Trzy kolejne artykuły - Violetty Rodek, Iwony Wendreńskiej oraz Ewy Szadzińskiej - prezentuja koncepcje dydaktyczne wywodzace się z ruchu "nowego wychowania". Ostatni artykuł, autorstwa Krystyny Wszołek przybliża nam koncepcję oceny szkolnej w ujęciu Kazimierza Sośnickiego.

Inicjujaca teza rozprawy autorstwa Sławomira Szobryna jest konstatacja o natywizmie i empiryzmie w pedagogice okresu międzywojennego, jako zjawisku binarnego przeciwieństwa występującego w naukach humanistycznych, a które autor potraktował jako podstawę do rozważania problemu - czy dydaktyka jest w ogóle możliwa. Celem rozważań było zatem sprawdzenie pedagogicznych konsekwencji wynikajacych $\mathrm{z}$ fenomenu owej dychotomii, która, jak się okazało, odegrała dość znaczną rolę w pojmowaniu kształcenia ogólnego.

W artykule Władysławy Szulakiewicz, podjęta została próba oceny wpływu przedstawicieli Szkoły Lwowsko-Warszawskiej na rozwój dydaktyki ogólnej okresu międzywojennego. W szczególności zaprezentowana została myśl dydaktyczna twórcy Szkoły - Kazimierza Twardowskiego oraz jego uczniów - Kazimierza Sośnickiego i Bogdana Nawroczyńskiego. Autorka, w świetle ich publikacji dydaktycznych trafnie dokonuje próby odpowiedzi na pytanie o wartość i esencje dydaktycznego dziedzictwa Szkoły Twardowskiego, która może okazać się inspirujaca w tworzeniu dydaktyki naszych czasów.

Danuta Drynda w swej pracy prezentuje cele kształcenia w dydaktyce Drugiej Rzeczypospolitej, sformulowane w świetle założeń pedagogiki kultury, wskazując ich charakter inspirujący współczesną edukację. W artykule ukazane sa idee dydaktyki ogólnej Sergiusza Hessena oraz Bogdana Nawroczyńskiego, które moga tworzyć punkt wyjścia dla współczesnych poszukiwań. Ponadto autorka przedstawia również cele kształcenia sformułowane przez reprezentantów pedagogiki kultury, ukazując ich inspirujący charakter dla współczesnej polskiej dydaktyki i teleologii dydaktycznej. Niewatpliwie rozważania te moga stać się podstawa dla teoretyków chcących uprawiać dydaktykę w oparciu o przedstawione w artykule koncepcje.

Celem rozprawy Violetty Rodek jest udowodnienie tezy, że idee ,szkoły pracy”, popularne i realizowane w okresie Drugiej Rzeczypospolitej, są wciąż aktualne i moga stanowić źródło inspiracji dla współczesnej edukacji. Artykuł niniejszy podzielony został na cztery powiazane ze sobą części. W części pierwszej ukazano główne idee nurtu „nowego wychowania” na tle krytyki szkoły tradycyjnej, i w nawiąaniu do niektórych założeń „,szkoły pracy”. Część druga prezentuje międzywojenne poglądy (zbieżne oraz kontrowersyjne) polskich przedstawicieli pedagogiki na temat „szkoły pracy”. W części trzeciej ukazane zostały niektóre polskie koncepcje ,szkoły pracy” powstałe w okresie Drugiej Rzeczypospolitej. Część ostatnia, to prezentacja argumentów przemawiajacych za aktualnościa niektórych idei tego kierunku. Autorka trafnie wskazuje wartości, występujące obecnie w kształceniu, które poparte idea ,,szkoły pracy”, moga rozwijać się w sposób bardziej dynamiczny i wszechstronny.

W historiografii pedagogicznej i dydaktycznej można znaleźć wiele publikacji opisujacych próby wprowadzenia planu daltońskiego do polskiego systemu edukacyjnego $w$ okresie Drugiej Rzeczypospolitej. W kilku z tych prac dokonano analizy i oceny wpływu tych prób na rozwój polskich innowacji dydaktycznych w okresie międzywojennym. Artykuł Iwony Wendreńskiej jest próbą prezentacji wpływu planu daltońskiego na współczesną dydaktykę ogólna, Autorka, charakteryzując plan daltoński oraz jego adaptację na terytorium Polski, specjalną uwage poświęca tym cechom innowacyjnym, które moga wpłynąć na rozwój obecnego systemu edukacyjnego. W pracy uchwycone sa współczesne odniesienia dydaktyki ogólnej, które maja swe korzenie w koncepcji planu daltońskiego oraz $w$ doświadczeniach wynikajacych $z$ jego realizacji $w$ okresie międzywojennym.

Kolejny artykuł autorstwa Ewy Szadzińskiej, prezentuje społeczne i psychologiczne warunki idei ksztalcenia zintegrowanego i nauczania łącznego oraz wybrane zagadnienia tych koncepcji, tzn. cele i treści kształcenia, metodykę nauczania. Zarówno w kształceniu zintegrowanym, jak i wcześniej, w nauczaniu łącznym, respektuje się przede wszystkim indywidualne doświadczenia uczniów oraz zwraca się uwagę na aktywność jednostki, dlatego tak ważne sa idee owych kon- 
cepcji dla edukacji współczesnej, stąd trafność podjętej tematyki. Autorka udowadnia, że cele tresci i metody nauczania w obecnej edukacji oraz w edukacji historycznej, sa konwergentne.

Celem artykułu Krystyny Wszołek jest rozpoznanie możliwości zastosowania idei oceny szkolnej Kazimierza Sośnickiego jako źródla analizy $\mathrm{i}$ oceny zjawisk obserwowanych $w$ okresie Drugiej Rzeczypospolitej oraz obecnie. W pracy wyeksponowana zostala użyteczność koncepcji oceniania uczniów K. Sośnickiego w opisie i porównywaniu współczesnych podejšć do zagadnień oceniania uczniów. K. Sośnicki ocenianie uczniów rozumiał bardzo szeroko i nowocześnie, był otwarty na wiele różnorodnych rozwiązań, co tym bardziej czyni jego koncepcję ważna dla współczesności. Szkoda tylko, jak trafnie zauwa- ża autorka, że myśl K. Sośnickiego nie miała wiekszego wpływu na tworzone obecnie projekty w zakresie oceny ucznia.

Podsumowując dokonaną powyżej analizę publikacji, należy stwierdzić, że wszystkie zawarte $w$ niej teksty sa oryginalne i zasługuja na uznanie, zwłaszcza w dobie reform oświatowych, jakie wciąz dokonuja się w Polsce. Jest to książka, która w sposób wyraźny zaznacza swoja praktyczną użyteczność. Należy wyrazić nadzieję, że pozycja ta będzie interesująca i pożyteczna zarówno dla profesjonalistów poszukujących obecnie nowego modelu dydaktyki ogólnej, jak i osób zajmujących się dydaktyką teoretycznie i praktycznie zorientowana.

Justyna Gulczyniska

\section{Juliusz Jundził, Wzorce i modele wychowania w rodzinie rzym- skiej w okresie III w. p.n.e. - III w. n.e., Bydgoszcz 2001, ss. 321}

Badania historii rodziny, zwłaszcza w odleglejszej przeszłości, starożytności czy średniowieczu, nie maja w polskiej historiografii wielkich tradycji. Na Zachodzie natomiast problematyka ta od drugiej połowy lat siedemdziesiątych była intensywnie uprawiana, glównie w aspektach badania życia codziennego, w tym także codziennej egzystencji rodzinnej, uwarunkowań funkcjonowania rodziny oraz relacji zachodzacych między nią a społeczeństwem.

$\mathrm{Na}$ naszym gruncie pierwszą książka poświęconą dziejom wychowania $w$ rodzinie w epoce starożytnej, a rzymskiej w szczególności, była praca Juliusza Jundziłła pt. Teoretyczne problemy wychowania $w$ rodzinie rzymskiej (III w. p.n.e. - III w. n.e.), Bydgoszcz 1987. Kilkanaście lat, jakie minęly od tego czasu, w pełni uzasadniaja jej ponowne wydanie. Tym bardziej, że Autor zmieniając tytuł nowego wydania, gruntownie książkę poprawił, uaktualniając jej treść z punktu widzenia najnowszych badań w zakresie tej problematyki, pisząc niektóre partie książki wręcz od nowa.

Nowo wydana książka ma tym większe znaczenie, iż nadal $w$ literaturze przedmiotu nie mamy do czynienia $\mathrm{z}$ szersza penetracja zagad- nienia wychowania rodzinnego $w$ Rzymie (jak i zreszta w Grecji), nie wspominajac o podejściu teoretycznym. Przedstawiona tu książka stanowi więc dopelnienie zachodniego nurtu badawczego reprezentowanego przez takich historyków, jak np.: K. Bradley, J. Nêuraudau, B. Rawson i S. Treggiari.

Monografia składa się ze wstępu, pięciu rozdziałów oraz zakończenia, bibliografii, indeksu i streszczenia w języku angielskim. Prezentowane $w$ niej badania dotycza funkcjonowania rodziny rzymskiej, od okresu rozkwitu Republiki po czasy schyłku Wczesnego Cesarstwa. Autor wychodzi od pogląów na wychowanie w rodzinie w czasach hellenistycznych a następnie omawia poglądy Cycerona, jednego $\mathrm{z}$ najwybitniejszych autorytetów moralnych i filozoficznych ostatniego wieku Republiki. Następnie analizie poddano zespół zapatrywań na wychowanie w rodzinic powstały w okresie przejściowym od Republiki do Cesarstwa, czyli w czasie pryncypatu Augusta, przełomowego dla formowania pogladów na temat rodziny i wychowania doby Cesarstwa. Dwa ostatnie rozdziały omawiaja poglady stoików rzymskich oraz odzwierciedlenie tych problemów w historiografii i literaturze pięknej. 